\title{
CHEMOTHERAPY OF PNEUMOCOCCIC MENINGITIS WITH SPECIAL REFERENCE TO SULFATHIAZOLE
}

\author{
By FRANK B. COOPER, PAUL GROSS, AND MARION L. HAGAN \\ (From the Western Pennsylvania Hospital Institute of Pathology, Pittsburgh)
}

(Received for publication November 15, 1941)

Because the sulfathiazole content of the brain and cerebrospinal fluid is admittedly low compared to that of the blood during medication, it has recently been claimed, in the absence of pertinent experimental or clinical data, that sulfathiazole is of little or no value in treating bacterial meningitis (1 to 4). Although it is not the purpose of this paper to advise the continued use of sulfathiazole in clinical cases of meningitis or to recommend to the clinician the use of any one of the sulfonamides in preference to the others, the experimental data presented and the clinical cases collected from the literature show that the above claim ( 1 to 4 ), as well as certain other disseminated opinions, require modification.

\section{METHOD}

Two hundred rats of approximately 200 grams weight were lightly anesthetized with ether and infected intracranially with approximately one fatal dose of Type II pneumococci. The animals were divided into five groups: one served as control; the remaining four groups were treated orally with $100 \mathrm{mgm}$. of the various drugs suspended in 0.5 cc. of 15 per cent gum acacia $6,22,46$, and 96 hours after infection. One group was treated with sulfanilamide, one with sulfapyridine, one with sulfathiazole, and the last with sulfamethylthiazole (Table I). All fatalities were autopsied and those showing in- sufficient pneumococcic infection to explain death were not included in the experiment.

To ascertain the relationship between the concentration of sulfathiazole in the blood and brain, 45 similarly infected rats were given $100 \mathrm{mgm}$. of drug orally, followed by $100 \mathrm{mgm}$. 8 hours and 24 hours later. At the intervals indicated in Figure 1 a number of rats were lightly etherized and 0.5 cc. of blood was withdrawn by cardiac puncture for analysis. No rat was bled more frequently than once during 24 hours. Rats were sacrificed after the 25-, 26-, 27-, 28-, 29-, and 30-hour bleedings and the drug content of the brain was determined. The analytical method employed was a modification of that of Bratton and Marshall (5) and has been shown statistically to give significantly higher recovery of sulfathiazole from blood, especially at $1: 20$ dilution (6).

\section{RESULTS}

Reference to Table I shows a 21-day survival of 18 per cent of the control group, compared to 84 per cent of the sulfanilamide group, 87 per cent of the sulfapyridine group, 79 per cent of the sulfathiazole group and 78 per cent of the sulfamethylthiazole group.

The concentration of sulfathiazole in the blood of rats receiving comparable treatment lay along a fairly smooth curve during the 7 hours following the first treatment (Figure 1). During the 6 hours following the 24-hour treatment, the con-

TABLE I

Type II pneumococcic meningitis in rats

\begin{tabular}{|c|c|c|c|c|c|c|c|c|c|c|c|c|}
\hline \multirow{2}{*}{ Treatment } & \multirow{2}{*}{$\begin{array}{c}\text { Number } \\
\text { of rats }\end{array}$} & \multicolumn{9}{|c|}{ Number of deaths daily during 21 days } & \multirow{2}{*}{$\begin{array}{l}\text { Number } \\
\text { of sur- } \\
\text { vivors }\end{array}$} & \multirow{2}{*}{$\begin{array}{l}\text { Per cent } \\
\text { survivors }\end{array}$} \\
\hline & & 1 & 2 & 3 & 4 & 5 & 6 & 7 & 8 & 9-21 & & \\
\hline $\begin{array}{l}\text { None........ } \ldots \ldots \ldots \ldots \ldots \\
\text { Sulfanilamide }(1) \ldots \ldots \ldots \ldots \ldots \\
\text { Sulfapyridine }(2) \ldots \ldots \ldots \ldots \ldots \\
\text { Sulfathiazole }(3) \ldots \ldots \ldots \ldots \\
\text { Sulfamethylthiazole }(3) \ldots \ldots \ldots\end{array}$ & $\begin{array}{l}40 \\
38 \\
39 \\
34 \\
37\end{array}$ & 16 & 13 & 2 & $\begin{array}{l}1 \\
1 \\
3 \\
1 \\
2\end{array}$ & $\begin{array}{l}2 \\
1 \\
2 \\
2\end{array}$ & $\begin{array}{l}2 \\
1 \\
3 \\
2\end{array}$ & 1 & 1 & $\begin{array}{l}1 \\
1 \\
1\end{array}$ & $\begin{array}{r}7 \\
32 \\
34 \\
27 \\
29\end{array}$ & $\begin{array}{l}18 \\
84 \\
87 \\
79 \\
78\end{array}$ \\
\hline
\end{tabular}

Infection: $0.1 \mathrm{cc}$. of a $10^{-6}$ broth dilution of an 18-hour broth culture (Binda, Type II) intracranially (approximately one fatal dose).

Treatment: $100 \mathrm{mgm}$. of drug suspended in $0.5 \mathrm{ccc}$. of 15 per cent gum acacia orally $6,22,46$ and 96 hours after infection (total $400 \mathrm{mgm}$.).

Drugs were synthesized and donated by (1) Monsanto Chemical Company, St. Louis, Missouri; (2) E. R. Squibb and Sons, New York City; and (3) The Maltbie Chemical Company, Newark, N. J. 


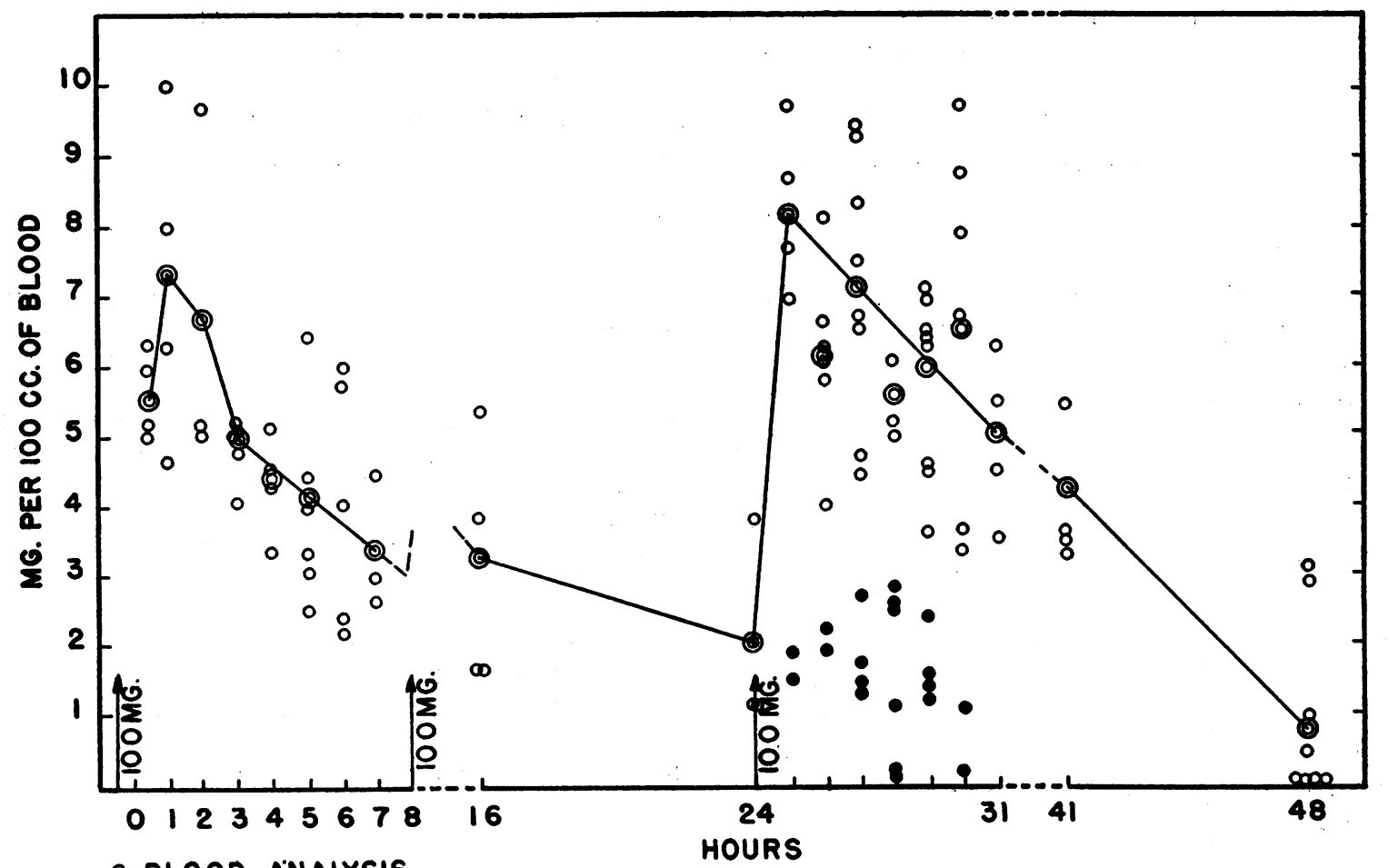

- blood analysis - average

- brain analysis

Fig. 1. Sulfathiazole Concentration in Blood and Brain of Meningitic Rats

centrations were higher and the variations greater. The brains of rats killed during the interval when blood concentrations varied from 3.5 to $10 \mathrm{mgm}$. per cent, and averaged 5 to $6 \mathrm{mgm}$. per cent, showed drug concentrations which varied from traces to $3 \mathrm{mgm}$. per cent and averaged approximately $1.6 \mathrm{mgm}$. per cent.

\section{DISCUSSION}

In a previous report (7) it was demonstrated that pneumococcic meningitis in rats is at least as severe as in man. In untreated animals, the occurrence of empyema of the cerebral ventricles and of the central canal of the cord was not uncommon. Extensions of the purulent meningitis into the nervous parenchyma occurred and were often associated with abscesses. Proof that the infection was not eliminated before lesions had become established was seen in the disturbances in gait and equilibrium in treated animals which recovered. Anatomic proof was obtained in the histologic sections of the brain and cord of these animals (8). The significant findings included thickened meninges with lymphocytic infiltration and vascular scars in the cerebral cortex with clusters of phagocytic cells, hemosiderin deposits and foci of calcification.

The infecting dose was purposely kept low so that successful treatment with the various drugs remained below the level known to cause kidney damage and its sequelae in rats (9 to 11$)$.

Because the greatest difference in group survival was 9 per cent, the results were tested for significance by the $x^{2}$ method. Taking the probability value of 0.05 as the criterion of significance, it was found that the differences observed among the treated groups were without statistical significance.

This proof that sulfanilamide, sulfapyridine, and sulfathiazole are equally effective in experimental pneumococcic meningitis of rats infected with the Binda Type II strain raises the interesting question of the relative importance of a high concentration of free drug in the cerebrospinal fluid for successful chematherapy of meningitis. The blood of infected rats which received 300 
mgm. of sulfathiazole in 24 hours (Figure 1), averaged 5 to $6 \mathrm{mgm}$. per cent of free drug; while the brains averaged $1.6 \mathrm{mgm}$. per cent and occasionally contained considerably less than $1 \mathrm{mgm}$. per cent.

\section{Chemotherapeutic results of clinical meningitis as collected from the literature}

The successful treatment with sulfathiazole of experimental pneumococcic meningtis in rats has its counterpart in the treatment of clinical meningitis. Table II lists not only 4 typed cases of pneumococcic meningitis but one case of streptococcic meningitis, 9 cases of staphylococcic meningitis, and 125 cases of meningococcic meningitis, the cure of which was attributed to therapy with sulfathiazole or its sodium salt.

The evaluation of the clinical efficacy of the various sulfanilamide drugs has resulted in rules which, on the whole, seem to be workable. However, several opinions disseminated in the medical literature appear, on the basis of subsequent clinical experience, to require modification. A case in point was the early and persistent assertions, frequently based on none too critical animal experiments, that sulfanilamide was of little or no value in pneumococcic infections (12 to 17 ) or was of value in treating only Type III pneumococcic infections (18 to 20). Disregard of these asser-

TABLE II

Pneumococcic, streptococcic, staphylococcic, and meningogoccic meningitis recoveries attributed to sulfathiazole

\begin{tabular}{|c|c|c|c|}
\hline Investigator & Trestment & Infection & $\begin{array}{l}\text { Number } \\
\text { of re- } \\
\text { coveries }\end{array}$ \\
\hline $\begin{array}{l}\text { Spink and Hansen ......... } \\
\text { Myers, Robb and Clapper ... } \\
\text { Land.................. } \\
\text { Ruegsegger and Hamburger. }\end{array}$ & $\begin{array}{l}\mathbf{S T}+\mathbf{S}+ \\
\mathbf{S T}+\mathbf{S M T}+ \\
\mathbf{S T}+\mathbf{S} \\
\mathbf{S T}+\mathbf{S}\end{array}$ & $\begin{array}{l}\text { Type III pneumococcus } \\
\text { Type I pneumococcus } \\
\text { Type I pneumococcus } \\
\text { Type III pneumococcus }\end{array}$ & $\begin{array}{l}1 \\
1 \\
1 \\
1\end{array}$ \\
\hline Knoll.................. & ST & $\beta$-hemolytic streptococcus & 1 \\
\hline 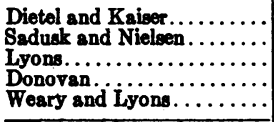 & \begin{tabular}{|l|} 
ST \\
ST+Na8T\$ \\
ST+F\| \\
NaST \\
ST
\end{tabular} & $\begin{array}{l}\text { Staphylococcus aureus } \\
\text { Staphylocoocus aureus } \\
\text { Staphylococcus } \\
\text { Staphylococcus } \\
\text { Staphylococcus }\end{array}$ & $\begin{array}{l}1 \\
1 \\
2 \\
1 \\
4\end{array}$ \\
\hline 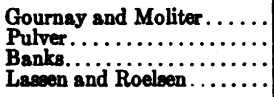 & $\begin{array}{l}\text { ST } \\
\text { ST } \\
\text { ST+NaST } \\
\text { ST }\end{array}$ & $\begin{array}{l}\text { Meningococcus } \\
\text { Meningococcus } \\
\text { Meningococcus } \\
\text { Meningococcus }\end{array}$ & $\begin{array}{r}1 \\
24 \\
94 \\
6\end{array}$ \\
\hline
\end{tabular}

* ST Sulfathiazole.

† S Type-specific antiserum.

† SMT Sulfamethylthiazole.

NaST Sodium salt of sulfathiazole.

II $\mathrm{H}$ Heparin.
TABLE III

Pneumococcic meningitis recoveries attributed to sulfanilamide

\begin{tabular}{|c|c|c|c|c|}
\hline Year & Investigator & $\begin{array}{l}\text { Treat- } \\
\text { ment }\end{array}$ & $\begin{array}{c}\text { Number of typed } \\
\text { recoveries }\end{array}$ & $\begin{array}{c}\text { Total } \\
\text { number } \\
\text { recov- } \\
\text { eries }\end{array}$ \\
\hline 1937 & $\begin{array}{l}\text { Mertins and Mertins } \\
\text { Mitehell and Trachsler } \\
\text { Basman and Perley }\end{array}$ & $\begin{array}{l}\mathbf{S A}^{*} \\
\mathbf{S A}+0 \dagger \\
\mathbf{S A}\end{array}$ & $\begin{array}{l}\text { IV } \\
\text { V } \\
\text { V }\end{array}$ & $\begin{array}{l}1 \\
1 \\
1\end{array}$ \\
\hline 1938 & $\begin{array}{l}\text { Latto } \\
\text { Rowe } \\
\text { Tixier, Eck, and Grossiard } \\
\text { Landon } \\
\text { Hubert } \\
\text { Finland, Brown and Rauh } \\
\text { Allan, Mayer and Williams } \\
\text { Young } \\
\text { Gubner } \\
\text { Moore } \\
\text { Query } \\
\text { Brasseur } \\
\text { Magruder and Nichols }\end{array}$ & $\begin{array}{l}\mathrm{N} \ddagger \\
\mathrm{SA}+\mathrm{N} \\
\mathrm{SA}+\mathrm{S} \\
\mathrm{N} \\
\mathrm{SA} \\
\mathrm{SA}+\mathbf{S} \\
\mathrm{SA} \\
\mathrm{SA} \\
\mathrm{SA} \\
\mathrm{SA} \\
\mathrm{SA}+\mathbf{S} \\
\mathbf{S A} \\
\mathrm{SA}\end{array}$ & 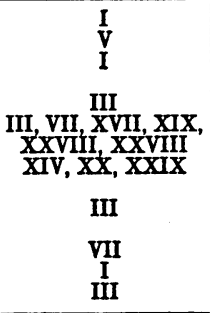 & $\begin{array}{l}1 \\
1 \\
1 \\
1 \\
1 \\
1 \\
6 \\
6 \\
3 \\
1 \\
1 \\
1 \\
1 \\
1\end{array}$ \\
\hline 1939 & $\begin{array}{l}\text { Dereux } \\
\text { Martin } \\
\text { Cathala } \\
\text { Kreinin } \\
\text { Hewell and Mitchell } \\
\text { Neal } \\
\text { Gray and Adams } \\
\text { Goldman } \\
\text { Canuyt } \\
\text { Lisansky and Pembroke } \\
\text { Toomey and Roach } \\
\text { Silverman and Thorner } \\
\text { Welch and Martin } \\
\text { Sappington and Favorite } \\
\text { Stewart and Martin } \\
\text { Hodes, Gimbell and Burnett }\end{array}$ & $\begin{array}{l}\text { SA+S } \\
\text { SA } \\
\text { SA } \\
\text { SA+S } \\
\text { SA } \\
\mathbf{N} \\
\mathbf{S A}+\mathbf{S} \\
\text { SA } \\
\text { SA } \\
\text { SA } \\
\text { SA }+\mathbf{S} \\
\text { SA } \\
\text { SA+N } \\
\text { SA } \\
\text { SA+N } \\
\text { SA }\end{array}$ & $\begin{array}{c}\text { VII } \\
\text { I, IV, VI, VII, XIII, } \\
\mathbf{X X I X}, \mathbf{X X X I} \\
\text { IV } \\
\text { XV } \\
\text { III } \\
\text { III } \\
\text { III } \\
\text { XXVIII } \\
\text { III }\end{array}$ & $\begin{array}{l}1 \\
1 \\
1 \\
1 \\
1 \\
7 \\
1 \\
1 \\
1 \\
4 \\
1 \\
1 \\
1 \\
1 \\
1 \\
1 \\
1 \\
1\end{array}$ \\
\hline 1940 & $\begin{array}{l}\text { Yampolsky } \\
\text { Diehl } \\
\text { Hamby, Sherman, Greene and } \\
\text { Whitebeky } \\
\text { Rhoads, Hoyne, Levin, Hors- } \\
\text { well, Reals and Fox }\end{array}$ & $\begin{array}{l}\text { SA } \\
\text { SA } \\
\text { SA+B } \\
\text { SA }\end{array}$ & I, VI, XVII, XXXI & $\begin{array}{l}1 \\
1 \\
1\end{array}$ \\
\hline & Total & & 42 & 55 \\
\hline
\end{tabular}

tions, fostered perhaps by the successful treatment of experimental Type I, II, and III pneumococcic meningitis in rats $(7,21,22)$, has resulted in reports of 55 cases of pneumococcic meningitis whose recovery is attributed to sulfanilamide and, in several instances, to the less effective neoprontosil (Table III). Among the recoveries, 42 cases were typed and 16 received serum in conjunction with the chemotherapy. Similarly, sulfapyridine, which was considered the drug of choice for treating pneumococcic infections before the advent of sulfathiazole, is reported to have saved 88 cases of pneumococcic meningitis (Table IV). In this series, 57 cases were typed and 29 received type-specific serum as an adjuvant to the chemotherapy. A number of recoveries which received both sulfanilamide and sulfapyridine were not included in Tables III and IV. 
TABLE IV

Preumococcic meningitis recoveries attributed to sulfapyridine

\begin{tabular}{|c|c|c|c|c|}
\hline Year & Investigator & Treatment & Number of typed recoveries & $\begin{array}{c}\text { Total } \\
\text { number } \\
\text { recoveries }\end{array}$ \\
\hline 1938 & $\begin{array}{l}\text { Reid and Dyke } \\
\text { Robertson }\end{array}$ & $\begin{array}{l}\text { SP* } \\
\text { SP }\end{array}$ & & $\begin{array}{l}1 \\
1\end{array}$ \\
\hline 1939 & $\begin{array}{l}\text { Robertson } \\
\text { Silverthorne, Brown and Auger } \\
\text { Hughes } \\
\text { Barnett, Hartmann, Perley and Ruhoff } \\
\text { Bolzinger } \\
\text { McAlpine and Thomas } \\
\text { Cutts, Gregory and West } \\
\text { Robinson } \\
\text { Yule } \\
\text { Raman } \\
\text { MacKeith and Oppenheimer } \\
\text { Dunlop and Laurie } \\
\text { Cable } \\
\text { Toomey and Roach } \\
\text { Pearson } \\
\text { Reid } \\
\text { Haley } \\
\text { Rawlings and Hamilton } \\
\text { Hodes, Gimbel and Burnett } \\
\text { Holmes } \\
\text { Taylor and Chitkara } \\
\text { Klemperer }\end{array}$ & $\begin{array}{l}\text { SP } \\
\text { SP } \\
\text { SP } \\
\text { SP } \\
\text { SP } \\
\text { SP } \\
\text { SP+S† } \\
\text { SP+S } \\
\text { SP } \\
\text { SP } \\
\text { SP } \\
\text { SP } \\
\text { NaSP } \\
\text { SP } \\
\text { SP } \\
\text { SP } \\
\text { SP } \\
\text { SP } \\
\text { SP } \\
\text { SP } \\
\text { SP } \\
\text { SP+S }\end{array}$ & $\begin{array}{c}\text { V, XIV } \\
\underset{I}{\text { XX }} \\
\underset{\text { III, IV }}{\text { XIV }}\end{array}$ & $\begin{array}{l}1 \\
2 \\
1 \\
3 \\
1 \\
1 \\
1 \\
1 \\
1 \\
1 \\
2 \\
1 \\
1 \\
1 \\
2 \\
1 \\
1 \\
1 \\
8 \\
1 \\
1 \\
1\end{array}$ \\
\hline 1940 & $\begin{array}{l}\text { Scott } \\
\text { Terry and Beard } \\
\text { Frist and Rippy } \\
\text { Herman } \\
\text { Moore and Forbes } \\
\text { Elvidge and Roseman } \\
\text { MacKay and Hurteau } \\
\text { Reid and Lipscomb } \\
\text { Falla } \\
\text { Vukov } \\
\text { Wetherell } \\
\text { Dawnay } \\
\text { Rhoads, Hoyne, Levin, Horswell, Reals and Fox } \\
\text { Turnof, Marenus and Schnabel } \\
\text { Coleman } \\
\text { Leichenger and Abelson } \\
\text { Quirk } \\
\text { Neal, Appelbaum and Jackson }\end{array}$ & $\begin{array}{l}\text { SP } \\
\text { SP } \\
\text { SP } \\
\text { SP+S } \\
\text { SP } \\
\text { SP+S } \\
\text { SP+S } \\
\text { SP+NaSP } \\
\text { SP } \\
\text { SP }+ \text { S } \\
\text { SP } \\
\text { SP }+ \text { S } \\
\text { SP } \\
\text { SP } \\
\text { SP } \\
\text { SP+S } \\
\text { SP } \\
\text { SP+S }\end{array}$ & $\begin{array}{l}\text { III } \\
\text { XIV } \\
\text { III } \\
\text { XVIII } \\
\text { XVIII } \\
\text { I, III, XXIII } \\
\text { XIX } \\
\text { XI } \\
\text { XIX } \\
\text { X, XVIII, XXIII } \\
\text { III } \\
\text { XIX } \\
\text { I, III, IV, IV, V, V, XV, } \\
\text { XVIII, XIX, XXXII }\end{array}$ & $\begin{array}{l}1 \\
1 \\
1 \\
1 \\
1 \\
1 \\
4 \\
1 \\
2 \\
1 \\
1 \\
1 \\
3 \\
1 \\
2 \\
1 \\
1 \\
10\end{array}$ \\
\hline 1941 & $\begin{array}{l}\text { Craddock and Bowers } \\
\text { Palmer } \\
\text { Musser } \\
\text { Cavanaugh } \\
\text { Vogelius } \\
\text { Hertz } \\
\text { Wilderman } \\
\text { Cunningham and Williams } \\
\text { Stites, Bell and Jelsma } \\
\text { Wolfermann and Whittaker } \\
\text { Thompson and Ward } \\
\text { Ludlum and Peterson }\end{array}$ & $\begin{array}{l}\text { SP } \\
\text { SP+S } \\
\text { SP+S } \\
\text { SP } \\
\text { SP+S } \\
\text { SP+NaSP } \\
\text { SP+S } \\
\text { SP+NaSP } \\
\text { NaSP+S } \\
\text { SP+NaSP+S } \\
\text { SP+S } \\
\text { SP }\end{array}$ & $\begin{array}{c}\text { XXVIII } \\
\text { XIX } \\
\text { VII } \\
\text { XIV } \\
\text { XXIII } \\
\text { VI } \\
\text { Group E } \\
\text { III } \\
\text { I,I } \\
\text { XIII } \\
\text { XIII }\end{array}$ & $\begin{array}{l}1 \\
1 \\
1 \\
1 \\
3 \\
2 \\
2 \\
1 \\
1 \\
1 \\
2 \\
1 \\
1\end{array}$ \\
\hline & Total & & 57 & 88 \\
\hline
\end{tabular}

* SP Sulfapyridine.

† S Serum.

$\ddagger$ NaSP Sodium salt of sulfapyridine. 
In view of the fact that a review of the literature prior to the introduction of the sulfonamides showed but 30 recoveries from pneumococcic meningitis during the preceding 15 years $(23)$, the report of 55 cures by sulfanilamide within the last 4 years, and four cures by sulfathiazole within less than one year leaves no reasonable doubt of the efficacy of these drugs. However, the conclusion reached in a recent review (24) that sulfanilamide and sulfapyridine were equally effective in treating pneumococcic meningitis is almost as unjustified on the basis of the statistical evidence available as the assertion that sulfanilamide and sulfathiazole are of questionable value in this disease.

Because of the lack of decisive data at present, it is not possible to judge which of the sulfonamide drugs, if any, is significantly superior in the clinical treatment of pneumococcic meningitis. Future decision on this point awaits not only the accumulation of sufficiently large numbers of cases treated with the various sulfonamides but the inclusion of the fatalities along with the cures in the data reported. Pertinent information concerning the efficacy of new drugs may also be obtained by the direct study of experimental pneumococcic meningitis and it is suggested that this method be used in preference to a reliance on the drug concentration in the cerebrospinal fluid.

\section{CONCLUSIONS}

1. Sulfanilamide, sulfapyridine, sulfathiazole, and sulfamethylthiazole are equally effective in the treatment of experimental Type II (Binda) pneumococcic meningitis in rats.

2. The sulfathiazole content of the brains of rats which received $300 \mathrm{mgm}$. of sulfathiazole orally in 24 hours averaged $1.6 \mathrm{mgm}$. per 100 grams at the time the blood averaged 5 to $6 \mathrm{mgm}$. per $100 \mathrm{cc}$.

3. Data are presented which show that clinical pneumococcic meningitis has been successfully treated with sulfanilamide as well as with sulfapyridine.

4. Other clinical data show pneumococcic, streptococcic, staphylococcic and meningococcic meningitis recoveries which were attributed to sulfathiazole therapy in spite of the generally recognized low concentration of this drug in the cerebrospinal fluid.
5. Because of the lack of decisive data at present, it is not possible to judge which of the sulfonamide drugs is significantly superior in the clinical treatment of pneumococcic meningitis. Future decision on this point awaits not only the accumulation of sufficiently large numbers of cases treated with the various sulfonamides but also the inclusion of the fatalities along with the cures in the data reported.

Note: While this paper was in press, Davis (25) presented experimental evidence which indicated that the sulfonamides are more or less closely bound to the albumen fraction of the blood, and for this reason the ratio of their "apparent" concentration in the blood to their actual concentration in the cerebrospinal fluid should not be used as a guide to the choice of drug for treating meningitis.

\section{BIBLIOGRAPHY}

1. Long, P. H., The clinical use of sulfanilamide and its derivatives in the treatment and prophylaxis of certain infections. Bull. New York Acad. Med., 1940, 16, 732.

2. Long, P. H., The clinical use of sulfanilamide, sulfapyridine, sulfathiazole, sulfaguanidine, and sulfadiazine in the prophylaxis and treatment of infections. Canad. M. A. J., 1941, 44, 217.

3. Alexander, H. E., Treatment of bacterial meningitis. Bull. New York Acad. Med., 1941, 17, 100.

4. Bowers, W. C., Infections of the middle ear and nasal sinuses. Bull. New York Acad. Med., 1941, 17, 453.

5. Bratton, A. C., and Marshall, E. K., Jr., A new coupling component for sulfanilamide determination. J. Biol. Chem., 1939, 128, 537.

6. Cooper, F. B., Gross, P., and Lewis, M., Determination and distribution of sulfathiazole in blood. Am. J. Clin. Path., 1942, 12, 149.

7. Gross, P., and Cooper, F. B., The chemotherapy of experimental Type II pneumococcic meningitis. Am. J. M. Sc., 1939, 197, 609.

8. Gross, P., Cooper, F. B., and Lewis, M., Repair in experimental pneumococcic meningitis. Am. J. Path., 1939, 15, 193.

9. Gross, P., Cooper, F. B., and Lewis, M., Urinary calculi caused by sulfapyridine. Urol. and Cutan. Rev., 1939, 43, 299.

10. Gross, P., Cooper, F. B., and Lewis, M., The fate of urinary calculi caused by the administration of sulfapyridine. Urol. and Cutan. Rev., 1939, 43, 439.

11. Gross, P., Cooper, F. B., and Scott, R. E., Urolithiasis medicamentosa. Urol. and Cutan. Rev., 1940, 44, 205.

12. Buttle, G. A. H., Gray, W. H., and Stephensen, D., Protection of mice against streptococcal and other 
infections by $p$-aminobenzenesulphonamide and related substances. Lancet, 1936, 1, 1286.

13. Whitby, L. E. H., The assessment of the efficiency of chemotherapeutic substances. Practitioner, 1937, 139, 650.

14. Pneumonia Commission, Medical Society of State of Pennsylvania, Pneumonia. Weekly Roster and Med. Digest, 1938, 33, 647, 686.

15. Current Comment, Sulfanilamide-pyridine. J. A. M. A., 1938, 111, 2122.

16. Long, P. H., Bliss, E. A., and Feinstone, W. H., The effects of sulfa-pyridine, sulfanilamide and related compounds in bacterial infections. Pennsylvania M. J., 1939, 42, 483.

17. Whitby, L. E. H., The treatment of septicemia. Current Med. Digest, 1939, 6, 321.

18. Buttle, G. A. H., Sulphanilamide chemotherapy. Lancet, 1939, 2, 371.
19. Buttle, G. A. H., Pharmacology of the sulphanilamide group of drugs. Brit. M. J., 1939, 2, 269.

20. Council on Pharmacy and Chemistry, Sulfanilamide. J. A. M. A., 1939, 112, 733.

21. Gross, P., Cooper, F. B., and Lewis M., Therapeusis of Type I pneumococcic meningitis in rats. Am. J. M. Sc., 1939, 198, 66.

22. Cooper, F. B., Gross, P., and Lewis, M., Sulfapyridine, sulfanilamide and specific antiserum in experimental Type III pneumococcic infections. J. Clin. Invest., 1939, 18, 423.

23. Mertins, P. S., and Mertins, P. S., Jr., Meningitis due to the Type IV pneumococcus, with recovery. Arch. Otolaryng., 1937, 25, 657.

24. Steele, C. W., and Gottlieb, J., Treatment of pneumococcic meningitis with sulfanilamide and sulfapyridine. Arch. Int. Med., 1941, 68, 211.

25. Davis, B. D., Binding of sulfonamides by plasma proteins. Science, 1942, 95, 78. 